\title{
FALLUJAH BATTLES: VIOLATIONS OF THE INTERNATIONAL HUMANITARIAN LAW
}

\author{
Rohaida Nordin ${ }^{1} \&$ Tareq Hamid \\ Universiti Kebangsaan Malaysia
}

\begin{abstract}
In April and November of 2004, the civilian population of Fallujah City experienced two extremely violent battles ("the Fallujah Battles") initiated by the Coalition Forces (CF) in Iraq. Marked by the killing and displacement of hundreds of thousands of people in Fallujah City, the Fallujah Battles raise a number of issues related to international humanitarian law (IHL), as well as concerns regarding the legal institutions charged with the protection of international human rights. This article generally discusses the crime allegedly committed against civilians by the CF - which included the USA, $U K$ and Iraqi forces - during the Fallujah Battles. The first part examines the principal IHL instruments considered in relation to acts that were committed during the Battles of Fallujah. The discussion then considers whether actions taken against civilians, civilian properties and medical units by the CF; and the prohibition of International Committee of Red Cross (ICRC) from carrying out its duties in wartime by the CF amount to violations of IHL. The second part considers whether the use of white phosphor constitutes a violation of contemporary IHL, particularly in relation to whether such weapons can be considered chemical weapons prohibited by IHL. Finally, this article discusses the potential legal mechanisms available to prosecute alleged perpetrators of war crimes in Fallujah.
\end{abstract}

Keywords: Fallujah battles, international humanitarian law, Geneva Conventions, war crimes, protection of civilians

\section{Introduction}

Following the defeat of the Iraqi military, Coalition Forces (CF), comprising predominantly UK and US forces, occupied and effectively controlled Iraq. After the effective occupation of Iraq, two major assaults were launched on Fallujah City resulting in

1 Corresponding author. 
civilian casualties ("Fallujah Battles”). On 5 April 2004, the US Marines engaged in a military operation in Fallujah, allegedly to arrest those responsible for the killing of four US security guards on 31 March. While Fallujah was under siege by the CF, daily airstrikes and other means were employed to achieve the objectives of the military operation. Sporadic fighting continued in Fallujah until the CF handed over control of the city to Iraqi forces. According to reports from the health authorities and the media, the number of those killed in the first Fallujah Battle in April 2004 numbered at least 600 people, with at least half of the casualties being civilians, including women and children. In the second Fallujah Battle, in November 2004, at least 3,000 civilians were reported to have been killed.

The Fallujah Battles resulted in the death and displacement of hundreds of thousands of civilians by the members of both the CF and Iraqi forces. Thus, it is important for this article to examine the acts committed during the Fallujah Battles in light of relevant IHL provisions contained within international conventions and treaties, including the four Geneva Conventions of 12 August 1949 (Geneva Conventions) among other international treaties. The discussion in this article will be divided into three parts. The first part provides a review of the relevant IHL instruments and examines whether the actions taken against civilians, civilian properties and medical units by the CF; and the prevention of the International Committee of Red Cross (ICRC) from carrying out its mandate during the conflicts by the CF amount to violations of IHL and war crimes. In the second part, the legality of the use of weapons in the Fallujah Battles, such as white phosphorous by the CF, will be examined in light of contemporary IHL. The analysis requires an investigation into the legality of the use of white phosphorus. Furthermore, evidence pertaining to the nature of the use of white phosphorous and its impact on the civilian population of the City of Fallujah will be considered. Finally, this article considers the potential legal mechanisms available to prosecute the alleged perpetrators of war crimes in Fallujah. The mechanisms considered include a special tribunal established by the United Nations (UN) Security Council; ${ }^{2}$ national courts with jurisdiction by virtue of being party to the relevant Geneva Conventions or by virtue of membership in the UN; and the International Criminal Court (ICC).

2 Hereinafter "Security Council." 
Before proceeding further, it has to be explained that this article is focusing on the violations of IHL by the CF and why such violations should be regarded as war crimes. This is because many violations of IHL may amount to war crimes. For example, direct attacks on residential neighbourhoods are grave breaches of the Additional Protocol I (API) and shall be regarded as war crimes according to Article 85(5) of the same protocol. Further, according to Article 147 of the Fourth Geneva Convention, the destruction and appropriation of property is a breach of the Convention. Such acts are considered war crimes under Article 85(5) of API. After discussing the violations of the IHL by the CF in Fallujah Battles, the violations should be viewed appropriately as war crimes, the intentional and/or indiscriminate targeting of civilians by military personnel. Members of the CF, acting as an occupying power, should bear the responsibility of the war crimes committed in Fallujah in accordance with the relevant provisions of international conventions.

\section{Violations of Geneva Conventions and International Conventions}

The section will analyse the actions of the CF during the Fallujah battles in light of the relevant IHL instruments. The first part discusses the relevant IHL instruments that will be used to analyse the facts surrounding the Fallujah Battles. The second part will consider the facts surrounding the Fallujah Battles and determine whether the CF violated provisions of the Geneva Conventions of 1949 during the Fallujah Battles, particularly in respect of the persecution and killing of civilians; and whether such actions constituted violations of Common Article 3 of the Geneva Conventions.

\section{a) A Review of Relevant IHL Instruments}

Following the Diplomatic Conference held in Geneva from April 21st to August 12th 1949,four Geneva Conventions were adopted for the purpose of establishing minimum standards for the treatment of members of the armed forces and the protection of civilians during times of armed conflict. Following the adoption of the Geneva Conventions, all relevant State parties involved in the Battle of Fallujah signed and/or ratified the conventions. ${ }^{3}$ The

3 Iraq ratified the Conventions on 14 February 1956; the United Kingdom ratified the Conventions on 23 September 1957; and the United States of America ratified the Conventions on 2 August 1955. 
standards established by the four Geneva Conventions apply to all armed conflicts of an international character, irrespective of whether the conflict is recognised as such by all parties involved in the hostilities. ${ }^{4}$ Furthermore, the standards established were also created to be applicable in situations where the armed conflict is not considered to be international in character, provided that the territory within which the hostilities occur are party to the Geneva Conventions. ${ }^{5}$ In light of the parties involved in the hostilities during the Fallujah Battles and the territory within which the hostilities occurred, no doubt remains as to whether the Geneva Conventions are applicable to the acts which were committed.

Additionally, two further protocols to the Geneva Conventions were adopted and opened for signature in Berne on 12 December 1977. The two Additional Protocols ${ }^{6}$ were adopted in an effort to further develop, rather than replace, the existing provisions concerning the protection of civilians during armed conflicts; and reinforce the relationship between the IHL standards prescribed by the Geneva Conventions and existing international human rights norms. ${ }^{7}$ Unlike the Geneva Conventions, the two instruments have not been endorsed by all parties involved during the Battles of Fallujah. ${ }^{8}$ Notwithstanding this fact, the API has been widely acknowledged and accepted by States in the international community; ${ }^{9}$ the substance of its provisions have largely been included in subsequent conventions and treaties dealing with IHL, including in Article 8 of the Rome Statute of

4 Common Article 2 of the Geneva Conventions.

5 Common Article 3 of the Geneva Conventions.

6 Protocol Additional to the Geneva Conventions of 12 August 1949, and Relating to the Protection of Victims of International Armed Conflicts (Protocol I) [Hereinafter “API”]; and Protocol Additional to the Geneva Conventions of 12 August 1949, and Relating to the Protection of Victims of Non-international Armed Conflicts (Protocol II) [Hereinafter “APII”].

7 Roberts, Adam and Richard Guelff .Documents on the Law of War. $3^{\text {rd }}$ Ed. Oxford: OUP, 2000. pp. 419-420.

8 The API was ratified by the UK on 28 January 1998; and by Iraq on 1 April 2010. The United States of America signed the API on 12 December 1977, but has not yet ratified the instrument. The APII was ratified by the UK on 28 January 1998. The United States of America signed the APII on 12 December 1977, but has not yet ratified the instrument. Iraq has not, as of the writing of this article, signed or ratified the APII.

9 Roberts, Adam and Richard Guelff. Documents on the Law of War. $3^{\text {rd }}$ Ed. Oxford: OUP, 2000. pp. 419-420. 
the International Criminal Court; ${ }^{10}$ and the provisions dealing with grave breaches have been argued to be customary international law by contemporary legal scholars. ${ }^{11}$ The API, which is also relevant to the events that occurred during the Fallujah Battles, is potentially applicable to the actions committed during hostilities despite the fact that it was not ratified by all parties to the conflict on the basis that it was considered to be customary international law at the time of the hostilities.

What remains to be determined is whether the Battles of Fallujah constituted armed conflicts within which civilians and non-military personnel were entitled to the protection established under the Geneva Conventions and the API. While there is a growing body of discourse concerning the applicability of IHL norms to noninternational armed conflicts, the simple matter is that this need not be considered in light of the provisions of the international instruments considered. Firstly, the Geneva Conventions explicitly extend the standards and protections guaranteed within their respective texts to situations of partial or total occupation of the territory of a State party to the Geneva Conventions. ${ }^{12}$ The API also explicitly extends its protection to the situations described within the text of the Geneva Conventions. ${ }^{13}$ Secondly, and most importantly, contemporary international legal norms automatically designate an armed conflict as international in nature when the conflict involves foreign intervention. The test applied to determine whether such intervention was sufficient to prove the existence of an international armed conflict involves determining whether the foreign party exercised effective control, which, in turn, is determined by the level of strategy, personnel and logistics involved in the intervention. ${ }^{14}$ The

10 Entry into force 1 July 2002.

11 See, Meron, Theodor. Human Rights and Humanitarian Norms as Customary Law. Oxford: Clarendon Press, 1989. pp. 62-78; and McDonald, Gabrielle Kirk and Olivia Swaak-Goldman. Substantive and Procedural Aspects of International Criminal Law: The Experience of National and International Courts. Vol. 1. Dordrecht: Kluwer Law International, 2000. p. 75-76.

12 Common Article 2 of the Geneva Conventions.

13 Article 1(3) of the API.

14 McDonald, Gabrielle Kirk and Olivia Swaak-Goldman. Substantive and Procedural Aspects of International Criminal Law: The Experience of National and International Courts. Vol. 1. Dordrecht: Kluwer Law International, 2000. pp. 80-81. 
magnitude of the intervention and involvement in the hostilities by the military forces of the UK and US, acting as part of the CF, clearly established this conflict as international in nature.

\section{b) Evidence on Violations in the Case of Fallujah Battles}

The following discussions will show that the CF violated several provisions of the Geneva Conventions, particularly Common Article 3 of the Geneva Conventions. The discussions will consider relevant evidence to prove that actions taken against civilians, civilian properties and medical units by the CF; and the prohibition of the ICRC from carrying out its duties in wartime by the CF amount to violations of IHL.

\section{i) Attacks against Civilians}

The first violation of IHL by the CF occurred in April 2004 as a result of the attacks on Fallujah. The hostilities resulted in the deaths of nearly 600 persons, the majority of whom were civilian residents. Most of the deaths were the direct result of the attacks, as many died in their houses after the CF prevented them from leaving the city during the fighting. Additionally, more than 30 civilians were killed after being attacked by an American F-16 fighter jet. The civilians were attacked while carrying white flags and trying to escape from the devastating situation within the City. ${ }^{15}$

The refusal of the CF to allow the citizens safe passage out of the City is a violation of Common Article 3 of the Geneva Conventions. These people took no active part in the hostilities and were accorded protection under Common Article 3(1) (a) of the Geneva Conventions. The direct attacks on residential neighbourhoods by the CF are grave breaches of the Additional Protocol I (API) and regarded as war crimes according to Article 85 (5) of the same protocol.

After the first battle of Fallujah, the CF planned a subsequent attack that led to the second battle of Fallujah, resulting in the deaths of thousands of civilians. On 25 and 26 December 2004, the

15 Testimonies of Crimes Against Humanity in Fallujah, report of Conservation Centre of Environmental \& Reserves in Fallujah (CCERF) is recorded in Iraqi Ministry of Planning \& International Cooperative under No. $1 Z 2129$. 
emergency unit of the Fallujah hospital recovered 700 bodies, 550 of which were women and children. ${ }^{16}$ The bodies were recovered from 9 of the 27 residential neighbourhoods. ${ }^{17}$ The CF later announced that they had held more than 1,200 bodies in refrigerated stores ${ }^{18}$ outside Fallujah. ${ }^{19}$ Article 50(3) of API provides that the existence of individuals within a civilian population that are not considered 'civilians' does not deprive the population of its civilian character. However, the CF violated Article 50(3) by targeting anything that moved in Fallujah City. According to the testimony of US soldiers that served in the US Army during the Fallujah Battles, any person in a house was a target to CF soldiers during the battles. The military operations and actions of the CF soldiers wantonly deprived the citizens of Fallujah of their civilian character.

In addition, in November 2004, a CF soldier fired on a wounded and unarmed Iraqi at point blank range in Fallujah. ${ }^{20}$ According to Amnesty International, the CF soldier claimed to have fired in the direction of a wounded insurgent. ${ }^{21}$ Killing a wounded person is a blatant violation of Common Article 3(1)(a) of the Geneva Conventions, as the provision accords protection to such individuals. The act was also a violation of Article23 of Hague Convention (IV), which forbids the killing or wounding of individuals belonging to a hostile nation or army; and the killing or wounding of an enemy who has surrendered. ${ }^{22}$ Furthermore, Article 32 of the Fourth Geneva Convention prohibits parties to the conflict from killing or murdering of protected persons in their hands, irrespective of whether the acts are committed by civilian or military agents.

16 IRIN, IRAQ: Death Toll in Fallujah Rising, Doctors say, Humanitarian News and Analysis Project of the UN Office for the Coordination of Humanitarian Affairs, accessible at http://www.irinnews.org/report.aspx?reportid=24527 (2 November2010).

17 Ibid.

18 The store was used for the storing of potatoes.

19 Letter from Fallujah to Kofi Annan. 2004 accessible at ahttp://www.uruknet. info/?p=9922 (28October2010).

20 Byers, M. War Law: Understanding International Law and Armed Conflict, Grove Press, New York, 2005, p 127.

21 Amnesty International, MDE 14/056/2004, News Service No: 287, 14 Nov 2004.

22 Convention (IV) Respecting the Laws and Customs of War on Land and its Annex: Regulations Concerning the Laws and Customs of War on Land. The Hague, 18 October 1907. 
According to Article 33 of the Fourth Geneva Convention, no protected person may be punished for an offence he or she has not personally committed. However, in the case in question, the actions of the CF led to the deaths of many civilians in their homes. As noted above, the remains of hundreds of civilians were recovered by Fallujah hospital. ${ }^{23}$ Furthermore, actions involving collective penalties, intimidation, terrorism, pillaging and reprisals against protected persons and property are prohibited. ${ }^{24}$ Arguably, the actions of the $\mathrm{CF}$ amount to collective penalties against civilians and their property and, as such, are considered tantamount to violations of Article 33.

Article 147 of the Fourth Geneva Convention states that protected persons shall not be subjected to death; torture; inhuman treatment; biological experiments that cause great suffering; unlawful deportation or transfer; unlawful confinement; wilful acts causing great suffering or serious injury; compulsory service in the forces of a hostile power; or deprivation of the right to a fair trial. ${ }^{25}$ Therefore, the civilian deaths, deportation and transfer of Fallujah civilians, as well as the inhuman treatment that occurred as a result of action taken by the CF, during the Fallujah Battles constitute violations of Article 147 of the Fourth Geneva Convention and Article 85 of the API.

\section{ii) Attacks on Civilian Objects}

During the second Fallujah Battle, the CF attacked residential neighbourhoods, resulting in the destruction of a large number of buildings. ${ }^{26}$ Approximately 26,000 houses were partially destroyed, while 3,000 more houses were completely destroyed. Additionally, 70 mosques and 50 schools were destroyed. ${ }^{27}$ The CF need to be

23 IRIN, IRAQ: Death Toll in Fallujah Rising, Doctors say, Humanitarian News and Analysis Project of the UN Office for the Coordination of Humanitarian Affairs accessibleathttp://www.irinnews.org/report.aspx?reportid=24527 (2November2010).

24 Article 33 of the Fourth Geneva Convention.

25 Aksar, Y. Implementing International Humanitarian Law From The Ad Hoc Tribunals To A Permanent ICC,Routledge,USA and Canada, 2004, p 115.

26 Keith, L. The Iraq Wars and America's Military Revolution. USA: Cambridge University Press. 2010, p 186.

27 Testimonies of Crimes Against Humanity in Fallujah, report of Conservation Centre of Environmental \& Reserves in Fallujah (CCERF) is recorded in Iraqi Ministry of Planning \& International Cooperative under No. 1 Z2129. 
held accountable for the damage caused to civilian properties. ${ }^{28}$ The destruction of these properties cannot be justified and constitute crimes against protected properties ${ }^{29}$ under Article 50 of the First Geneva Convention. The extensive destruction and appropriation of civilian property constitute grave breaches in accordance with provisions of the First Geneva Convention.

The bombing of homes and the widespread destruction that affected the City of Fallujah amounts to criminal practice and cannot be justified under military necessity. The CF initiated hostilities in Fallujah in retaliation for the killing of security company personnel in 2004. ${ }^{30}$ According to Article 147 of the Fourth Geneva Convention, the destruction and appropriation of property is a breach of the Convention. Such acts are also considered war crimes under Article 85(5) of API. Civilian objects are protected against reprisals according to Article 52 of API, which states:

- Civilian objects shall not be the object of attack or of reprisals. Civilian objects are all objects which are not military objectives as defined in paragraph 2.

- $\quad$ Attacks shall be limited strictly to military objectives. In so far as objects are concerned, military objectives are limited to those objects which by their nature, location, purpose or use make an effective contribution to military action.

- In case of doubt whether an object which is normally dedicated to civilian purposes, such as a place of worship, a house or other dwelling or a school, is being used to make an effective contribution to military action, it shall be presumed not to be so used.

During the second Fallujah Battle in 2004, the CF also violated provisions of the 1954 Hague Convention guaranteeing protection to cultural objects and places of worship. ${ }^{31}$

28 Ibid.

29 Bantekas, I and Nash, S. International Criminal Law. 3rd ed. USA: Cavendish Publishing Limited, 2007. p. 113.

30 Floyd. C. 2010. Devastating Aftermath of Fallujah Battle accessible at http:// www.darkgovernment.com/news/devastating-aftermath-of-fallujah-battle/ (08April 2011).

31 Article 2 of Hague Convention for the Protection of Cultural Property in the Event of Armed Conflict.Hague. 1954. 


\section{iii) Violations against Medical Units}

Under Article 55 of the Fourth Geneva Convention, the occupying power is responsible to ensure that food and medical supplies are provided to the civilian population. In the event that resources in the occupied territory do not meet the needs of the civilian population, the occupying force is responsible for ensuring a supply of necessary foodstuffs, medical stores and other articles. Furthermore, the occupying power is obligated under Article 56 of the Fourth Geneva Convention to maintain the operations of medical facilities, services and hospitals and is prohibited from taking over civilian hospitals except in cases arising under Article 57, which permit the requisition of a civilian hospital only in times of urgent necessity; and only if the needs of civilians requiring medical treatment can be accommodated. $^{32}$

The API obligates States to respect and protect medical personnel who provide services during any armed conflict. Medical personnel are entitled to go to any place to provide services, taking into consideration measures of security and surveillance undertaken by the parties to the conflict. Article 16 of the API seeks to ensure the protection of medical personnel, providing that persons engaged in medical activities shall not be compelled to perform acts or to carry out work contrary to medical ethics, or other medical rules, designed to benefit wounded and sick persons; or pursuant to the provisions of the Geneva Conventions or the API. The provisions also prohibit armed forces from preventing medical personnel from performing acts or from carrying out work required by those rules and provisions. Despite the obligations arising under the API, the CF prohibited the wounded from reaching hospitals and prohibited medical personnel from entering Fallujah City, thereby violating Article 16 of the API. ${ }^{33}$

32 Article 57 provides that "The Occupying Power may requisition civilian hospitals only temporarily and only in cases of urgent necessity for the care of military wounded and sick, and then on condition that suitable arrangements are made in due time for the care and treatment of the patients and for the needs of the civilian population for hospital accommodation. The material and stores of civilian hospitals cannot be requisitioned so long as they are necessary for the needs of the civilian population”.

33 Shiner, P. and Williams, A, 2008.The Iraq War and International Law. USA: Hart Publishing. p 96. 
From the beginning of the battles in Fallujah, the CF targeted medical transport and hospitals in Fallujah, and also acted against the staff of medical units and facilities. On 7 November 2004, the CF laid siege to Fallujah General Hospital, arresting the medical personnel present as well as the patients. ${ }^{34}$ This act violated Article 16 of the API and Article20 of the Fourth Geneva Convention. According to Article 20 of the Fourth Geneva Convention, the doctors and other staff of Fallujah hospital were protected persons. In spite of the clear protection of medical personnel under IHL, the CF attacked the general hospital at Fallujah and arrested the personnel of the hospital. ${ }^{35}$

In addition, US airstrikes destroyed Nazzal Hospital in the centre of Fallujah without any prior warning. ${ }^{36} \mathrm{Civilian}$ hospitals are considered protected civilian objects. The protection of civilian hospitals is not lifted unless they are used for military purposes or a warning has been issued. In such case, only after a reasonable time limit has passed and the warning has been ignored, does the protection end. ${ }^{37}$ Alongside the attacks on hospitals, there were also attacks on ambulances. ${ }^{38}$ Although, the medical vehicles shall be respected and protected, in the same way as mobile medical units under Article 21 of API, such IHL obligations were not respected by the CF. Therefore, the CF is responsible for targeting the medical units and medical transportation in Fallujah during the attack. CF actions against hospitals and medical transport constitute violations of Article 16 of the API, as well as Articles 18 and 20 of the Fourth Geneva Convention.

\section{iv) ICRC and the Hindrances from Carrying Out Its Duties in Wartime}

Additionally, States are obligated to protect humanitarian organizations and permit them to pursue activities of a humanitarian nature. Article 81(1) of the API is concerned with the activities

34 According to, interview with Gen. Rich Natonski. The commander of the Marine Division during the Fallujah Battles accessible at http://www.youtube. com/watch?v=0vGmScPNB5U (27 March 2011).

35 Shiner, P. and Williams, A, 2008.The Iraq War and International Law. USA: Hart Publishing.p 96.

36 Ibid. p 96.

37 Fourth Geneva Convention, Article 19.

38 Stjepan, G, M. Rules of Engagement? A Social Anatomy of an American War Crime Operation .Iron Triangle, Iraq.Algora Publishing, New York, 2008, p 73. 
of humanitarian organizations during times of armed conflict and provides that all parties to a conflict should grant all facilities within their control to enable the ICRC and other organisations to assist victims of conflicts, and any other measures undertaken in favour of the victims that the parties to the conflict have consented. Article 81(2) expressly extends the protection to national humanitarian organizations, such as national societies of the Red Crescent. ${ }^{39}$ In most cases, the CF prevented such organizations ${ }^{40}$ from entering Fallujah and nearby towns and villages although the intention was to help hundreds of thousands of Fallujah refugees in need of basic necessities, such as water, food, medicine, electricity and shelter. ${ }^{41}$

\section{The Use of Illegal Weapons}

When the CF attacked Fallujah City during the Fallujah Battles they used illegal weapons, such as white phosphorus and incendiary weapons. The usage of these weapons by the CF was supported by the testimonies of witnesses and documentary evidence. This section will discuss the legal background concerning the banning of white phosphorus; evidence of the use of white phosphorus in Fallujah Battles; and the violation of IHL as the consequence.

\section{a) Legal Background on Banning of White Phosphorus}

IHL condones the use of weapons that incapacitate the enemy, but it is not an open ended acceptance. ${ }^{42}$ Certain types and uses of weapons are prohibited on humanitarian grounds. Weapons permitted for use by armed forces include illuminating weapons, to enable sight during night battles; camouflage to conceal military units and personnel during the day; and weapons that can ignite material targets, such as ammunition or fuel stores. White phosphorous is suitable for many of these tasks because it ignites easily when exposed to oxygen and produces dense white smoke, capable of concealing or indicating potential military targets, as well as illuminating positions.

39 ICRC and IRCS.

40 Testimonies of Crimes Against Humanity in Fallujah, report of Conservation Centre of Environmental \& Reserves in Fallujah (CCERF) is recorded in Iraqi Ministry of Planning \& International Cooperative under No. 1 Z2129.

41 Testimonies of Crimes Against Humanity in Fallujah, report of Conservation Centre of Environmental \& Reserves in Fallujah (CCERF) is recorded in Iraqi Ministry of Planning \& International Cooperative under No. 1Z2129. 
White phosphorus can be delivered to a target by artillery, mortar or hand grenade due to its favourable smoke to weight ratio. ${ }^{43}$ Commonly used white phosphorus projectiles include illuminating rounds, that dispense flares on parachutes; and smoke rounds, that either eject canisters or felt wedges that fall to the ground, burn and emit smoke.

Although white phosphorus is chemical in nature, it is not classified as a chemical weapon. In order to prove that white phosphorus can be classified as a prohibited chemical weapon, it must be analysed in light of the Chemical Weapons Convention ${ }^{44}$ (CWC). In that instance one would have to demonstrate that it constitutes a de jure 'chemical weapon' in accordance with the Convention and that its military uses are prohibited by the CWC.$^{45}$ If one considers white phosphorus as a chemical weapon, due to its various harmful physiological effects, it is a de jure toxic chemical and, as such, is prohibited by the CWC. ${ }^{46}$

Article 1(1) of the CWC contains comprehensive prohibitions on certain activities regarding the development, production, stockpiling and use of chemical weapons. However, this apparent total ban has to be read in the light of Article 2, the definitions and criteria that provide the foundation for the CWC, and Article 6, which describes weapons not prohibited under the Convention. ${ }^{47}$

It may be worth adding that although white phosphorus can be considered both a 'chemical weapon' and a 'toxic chemical' under Articles 2(1) and 2(2), respectively, Article 2(9) allows the use of chemicals for military purposes that do not rely on the toxic properties of the chemical as a method of warfare.

43 MacLeod. I.J and Rogers A.P.V. 2009.The Use of WP and the Law of War. Yearbook of International Humanitarian Law 10. 76.

44 Which was adopted by the General Assembly on 30 November 1992, in its Resolution entitled Convention on the Prohibition of the Development, Production, Stockpiling and Use of Chemical Weapons and on Their Destruction (A/RES/47/39).

45 MacLeod, I.J. and Rogers, A.P.V. 2007.Yearbook of International Humanitarian Law. Volume10. pp. 75-97. No publisher. p 95.

46 Ibid. p 96.

47 According to Article 6 of CWC, which give the permission to develop and produce the chemical weapons and adopt the necessary measures to ensure those toxic chemicals and their precursors are only developed and produced used within its territory of the state or in any other place under its jurisdiction or control for not prohibited purposes under CWC. 
The Convention on Certain Conventional Weapons (CCW $)^{48}$ places restrictions and prohibitions on the use of certain weapons to prevent inhumane injuries to soldiers and indiscriminate injuries to non-combatants. The Convention was initially designed to deal only with international armed conflicts. However, with the rise of noninternational armed conflicts throughout much of the early 1990s, a protocol was adopted in 1996 that prohibited the use of mines, booby traps and other devices during internal armed conflicts. ${ }^{49}$

The CCW is an umbrella Convention, meaning that it only contains general provisions. The substantive provisions concerning the restriction and prohibition of specific weapons are found in the protocols to the Convention. The CCW required States to consent to a minimum of two of the three protocols. Protocol III, which entered into force at the same time as the CCW, deals with incendiary weapons. ${ }^{50}$ Article 2 of Protocol III prohibits the targeting of civilians and civilian objects when utilising incendiary weapons; prohibits the use of air-delivered incendiary weapons on targets in close proximity to civilians; prohibits the use of any other incendiary weapons in close proximity to civilian populations unless the damage can be limited to the military objective without significant injury or loss of life to the civilian population; and prohibits the use of incendiary weapons in forests or other forms of plant cover except when such natural elements are used to camouflage or conceal combatants or military objectives.

Thus, it is clear from the above reviews that although white phosphorus is chemical in nature, it is not classified as a chemical weapon. However, due to its various harmful physiological effects, it is a de jure toxic chemical and, as such, is prohibited by the CWC.

48 UN Convention on Prohibitions or Restrictions on the Use of Certain Conventional Weapons Which May Be Deemed to Be Excessively Injurious or to Have Indiscriminate Effects as amended on 21 December 2001(CCW) is usually referred to as the Convention on Certain Conventional Weapons. It is also known as the Inhumane Weapons Convention.

49 Article 1(3) of the Amended Protocol on Prohibitions or Restrictions on the Use of Mines, Booby-Traps and Other Devices (1996 Amended Protocol II), entry into force 3 December 1998.

50 The United States of America, with reference to Article 2, paragraphs 2 and 3, reserves the right to use incendiary weapons against military objectives located in concentrations of civilians where it is judged that such use would cause fewer casualties and/or less collateral damage than alternative weapons. 


\section{b) Evidence of the Use of White Phosphorus in the Fallujah Battles}

The CF used incendiary weapons (MK-77) during the second Fallujah Battle against the Fallujah civilians. These bombs have a similar destructive effect to napalm,,$^{51}$ and, for this reason, the CF violated both the CCW and Article 2(1) of Protocol III.

According to Dr Ahmed of the Fallujah General Hospital, ${ }^{52}$ the rate of birth defects and cancers increased after the two battles in Fallujah in 2004 because of the pollution and radiation emitted from white phosphorus and other weapons. Dr Chris Busby ${ }^{53}$ studied the increase of cancer, birth defects and the issue of infant deaths that affected the population in Fallujah City after the battles, concluding that the cancer rate and infant mortality rate were alarmingly high compared to the statistics on the rates before the battles. White phosphorus and weapons containing depleted uranium had contaminated the environment, leading to a reduction in the sex ratio of the children born within one year of the end of the battles in $2004 .{ }^{54}$

On 8 November 2004, a documentary film was aired about the battles of Fallujah on Italian television. The film alleged that the US forces had used artillery to fire white phosphorus indiscriminately against human targets in November 2004, and, thus, had violated IHL governing the usage of incendiary devices. ${ }^{55}$ The CF used massive quantities of white phosphorus during the second battle of Fallujah, ${ }^{56}$ which increased the cancer rates in children, particularly

51 Testimony in the Fallujah, the Hidden Massacre film, which were presented in Italian channel documentaries accessible at http://video.google.com/videoplay ?docid=8905191678365185391\# (25 March 2011).

52 Monitoring Net of Human Rights in Iraq Environmental. 2008. Prohibited Weapons Crisis, The Effects of Pollution on the Public Health in Fallujah. Presented to 7th session of the Human Rights Council. Geneva, 3 - 28 March.

53 Busby, C. Hamdan. M and Ariabi. E. 2010. Cancer, Infant Mortality and Birth Sex-Ratio in Fallujah, Iraq 2005-2009.International Journal of Environmental Research and Public Health accessible at http://www.mdpi.com/16604601/7/7/2828/pdf.(09 November 2010)

54 Ibid.

55 Solis, G, D. The law of Armed Conflict. Cambridge University Press, New York, 2010, p 598.

56 Popham, P, the Independent Newspaper, 08 November 2005 accessible at http://www.thewe.cc/weplanet/news/americas/us/war_crimes_fallujah.html (19 October 2010). 
leukaemia, as well as birth defects. ${ }^{57}$ The military journal of the US also noted the use of white phosphorus in the following passage:

White phosphorus proved to be effective and versatile munitions. We used it for screening missions at two breeches and, later in the fight, as a potent psychological weapon against the insurgents in trench lines and spider holes when we could not get effects on them with high explosive. We fired 'shake and bake' missions at insurgents, using white phosphorus to flush them out and high explosive to take them out ${ }^{58}$

\section{c) The Violations of IHL}

The use of white phosphorus in Fallujah was illegal and inconsistent with IHL norms. The CF could not ascertain whether the people in Fallujah were combatants at the time of the attacks. IHL requires armed forces to exercise the utmost regard for civilian life and, given the fact that the CF prevented civilians from leaving Fallujah during the battles, it was known that many civilians remained in Fallujah during the attacks.

Although the UN Security Council authorised the CF to restore public order and safety, this authorization did not include permission to indiscriminately kill civilians. On the contrary, UN Security Council Resolution 1483, adopted in 2003,59 required the CF to treat civilians humanely and protect them from violence. Although the CF was charged with the restoration of public order and safety, the exception for the use of chemical weapons for law enforcement purposes does not apply for two reasons. First, the CF was considered an occupying force during the Fallujah Battles, placing them firmly within the scope of IHL norms. Secondly, the methods and means of the engagement were inconsistent with traditional law enforcement activities.

57 Busby, C. Hamdan.M and Ariabi. E. 2010. Cancer, Infant Mortality and Birth Sex-Ratio in Fallujah, Iraq 2005-2009.International Journal of Environmental Research and Public Health accessible http://www.mdpi.com/16604601/7/7/2828/pdf. (09 November2010).

58 MacLeod, I.J. and Rogers, A.P.V. 2007.Yearbook of International Humanitarian Law. Volume10. pp. 75-97. No publisher. p 78.

59 Adopted by the Security Council at its 4761st meeting, on 22 May 2003. 
Therefore, the use of white phosphorus by CF in the battles of Fallujah was contrary to the CWC and IHL norms relating to the status of the CF as an occupying power in Iraq and the means and methods associated with the military operations conducted while trying to restore public order and safety. The use of white phosphorus during the Fallujah Battles violates Articles 27 and 29 of the Fourth Geneva Convention, requiring civilians to be treated humanely and protected from violence; and Article 2 of CCW Protocol III, concerning the use of incendiary weapons near civilian populations.

Finally, the use of white phosphorus smoke entails the use of the weapon as a chemical weapon during military operations. The lawful use of chemicals for law enforcement purposes does not apply to the Fallujah Battles, since the CF violated the CWC by using a chemical weapon against civilians in Fallujah.

\section{Legal Mechanisms to Prosecute the Perpetrators of War Crimes}

After discussing the violations of the IHL by the CF in Fallujah Battles, the violations constitute war crimes, particularly in regards to the intentional and/or indiscriminate targeting of civilians by military personnel. The assaults on the physical integrity and personal security of civilians; the bombing and destruction of civilian residential areas; and the destruction of cultural sites and places of worship were also violations of IHL. Members of the CF, acting as an occupying power, should bear the responsibility of the war crimes committed in Fallujah in accordance with the relevant provisions of international conventions.

Several international legal mechanisms exist in contemporary practice to prosecute those responsible for violations of IHL and committed war crimes. Such mechanisms could be utilised to prosecute members of the CF who have committed violations of IHL and war crimes during the battles of Fallujah. Potential mechanisms include the following:

- $\quad$ A special tribunal established by the UN Security Council, for the prosecution of war crimes committed during the Fallujah Battles.

- The national courts of States party to the Fourth Geneva Convention could prosecute members of the CF for war crimes. 
- The national courts of Member States of the UN could prosecute the war criminals of the CF according to the principle of international criminal jurisdiction.

- $\quad$ The International Criminal Court (ICC) mechanism could be utilised to prosecute members of the CF.

\section{a) The Establishment of a Special Tribunal for War Crimes}

The Security Council is empowered to act in relation to the events that occurred in Fallujah, particularly in regards to potential international criminal acts perpetrated by the CF against the people of Fallujah. The acts committed by the CF after its occupation of Iraq in 2003, given the international legal nature of the offences, are correctly denoted as 'international crimes'. Considering the number of unarmed and innocent civilians that were killed during the Fallujah Battles, the situation warrants consideration by the UN Security Council regarding the establishment of an international criminal tribunal for the prosecution of members of the CF that committed grave breaches of IHL.

The Security Council established the International Criminal Tribunal for Former Yugoslavia (ICTY) pursuant to Resolution 808(1993), ${ }^{60}$ empowering the tribunal to prosecute persons responsible for genocide; crimes against humanity in international and internal conflicts; grave breaches of the Geneva Conventions; and other violations of IHL committed in the territory of the former Yugoslavia after January $1991 .{ }^{61}$ The Security Council also established the International Criminal Tribunal for Rwanda (ICTR) on 8 November1994 pursuant to Resolution 955(1994), ${ }^{62}$ which empowered the tribunal to prosecute individuals suspected to have committed genocide, crimes against humanity or serious violations of the laws of war in Rwanda between January and December $1994 .{ }^{63}$ On 14 August 2000, the Security Council requested, in Resolution

60 Aksar, Y. Implementing International Humanitarian Law From The Ad Hoc Tribunals To A Permanent ICC,Routledge,USA and Canada, 2004,p20. Resolution 808, adopted by the UN Security Council on 22 February 1993.

61 Eve La,Haye.War Crimes in Internal Armed Conflicts, Cambridge University Press, New York, 2008, p 134.

62 The Resolution adopted by the Security Council at its 3453rd meeting expressed its grave concern at the reports indicating that genocide and other systematic, widespread and flagrant violations of international humanitarian law have been committed in Rwanda.

63 Ibid. p 137. 
1315 (2000), that the Secretary-General of the UN, in cooperation with the Sierra Leone Government, establish an independent special court, recommending that its jurisdiction include crimes against humanity, war crimes and other violations of international law. ${ }^{64}$ According to Article 3 of the Agreement, dated 16 January 2002, between the UN and the government of Sierra Leone, a prosecutor was appointed on the basis of a consultation between the two institutions. The Special Court is mandated to function in accordance with the Statute of the Special Court for Sierra Leone, which forms an integral part of the agreement between the UN and the government of Sierra Leone on the establishment of the Special Court. ${ }^{65}$ Such UN Security Council Resolutions are considered to be a translation of the powers provided in Chapter VII of the UN Charter concerning the powers of the Security Council in cases that threaten international peace, or breach the peace, with the aim of restoring or maintaining international peace and security. ${ }^{66}$

Although the mission of the UN is to ensure international justice, security and peace, in reality, it may be difficult for the Security Council to establish an International Criminal Tribunal for Fallujah, because of the positions of the US and UK as permanent members with the right to veto Security Council resolutions. On the other hand, while the US has this right in the Security Council, that does not prevent the Security Council from attempting to establish an international criminal tribunal for acts committed in Fallujah if the international political equation ever permits such action. At present, both the UN system and the powers of the Security Council members would need to be reformed for such a resolution to pass.

\section{b) Jurisdiction of National Courts under the Fourth Geneva Convention}

Article 146 of the Fourth Geneva Convention requires State parties to enact domestic legislation to make its provisions enforceable domestically, as well as search for and prosecute persons who are suspected to have committed grave breaches of the Geneva Conventions.

\footnotetext{
64 Bantekas, I and Nash, S. International Criminal Law, Routledge Cavendish, USA, 2007, p 559.

65 Ibid. p 559.

66 Article 39 of the UN Charter.
} 
Article 148 of the Fourth Geneva Convention further provides that no State Party to the Convention is allowed to absolve itself or any other State Party to the Convention from liability resulting from grave breaches of the provisions of the Fourth Geneva Convention. Article 89 of the API to Geneva Conventions provides that:

\section{In the cases of serious violations to Geneva Conventions or of their Protocols, the High Contracting Parties undertake to act, jointly or individually, in cooperation with the United Nations and in conformity with the United Nations Charter.}

These legal provisions provide State parties with criminal jurisdiction over grave breaches of IHL. While the possibility exists that a State Party to the Fourth Geneva Convention will attempt to prosecute any individual for committing war crimes in Fallujah Battles, such provisions are seemingly ignored by the international community due to the lack of political will.

\section{c) Jurisdiction of National Courts of Member States of UN under the Principles of International Criminal Jurisdiction}

The Geneva Conventions obligate State parties to take legislative and executive measures to suppress war crimes and prosecute persons accused of the commission of such crimes. In 1946, the UNGA noted, in Resolution 3, that all States within the international community had jurisdiction over persons accused of the commission of war crimes and crimes against humanity, irrespective of whether the acts were considered criminal in the domestic law of the country in which they were committed. Furthermore, the UNGA emphasised that there was no statute of limitations for such crimes, irrespective of when they were committed. Universal jurisdiction applies to all grave breaches of IHL, allowing for the prosecution of any person, of any nationality, who is accused of committing such a crime, irrespective of where the crimes were committed.

Universal jurisdiction allows a complainant of one country to serve a writ against a national of another country while the alleged offender is physically present in the country of the complainant. A familiar precedent is that of former Chilean President General Pinochet, who was detained following his arrival in London for back 
surgery in September of $1998 .{ }^{67}$ Pinochet was detained as a result of a Spanish extradition warrant regarding his involvement in the torture and disappearance of Spanish citizens, as well as the torture, disappearance and deaths of Chilean nationals during his tenure in office. The warrant was exercised by the British police in the UK due to an extradition treaty between the UK and Spain. ${ }^{68}$ Similarly, Belgium has enacted domestic war crimes legislation covering serious violations of the Geneva Conventions and the Additional Protocols that allow for the prosecution of persons for war crimes irrespective of where they had been committed. ${ }^{69}$

\section{d) The Jurisdiction of the International Criminal Court (ICC)}

The Rome Statute established a permanent institution with jurisdiction over persons alleged to have committed serious war crimes. Civilians are protected by the ICC because the institution can prosecute individuals that have committed grave breaches of IHL. The possibility exists for persons who committed war crimes during the Fallujah Battles to be referred to the prosecutor of the ICC by the Security Council under Chapter VII of the UN Charter. In the event that this occurs, the ICC is entitled to exercise jurisdiction over the persons who have committed any of the international crimes referred to in Article 5 of the Rome Statute. If the criminal acts committed fall within the jurisdiction of the ICC, the Security Council can refer the matter to the Prosecutor of the ICC. ${ }^{70}$

However, the ICC should not be utilized to by-pass or contradict the primary role and function of the Security Council in matters of peace and security. ${ }^{71}$ Article 23 of the International Law Commission (ILC) draft statute entitled 'Action by the Security Council' depicts the relationship between the Security Council and ICC, stating: ${ }^{72}$

67 Van Cleave. R. A, 'The Role of United States Federal Courts in Extradition Matters: The Rule of Noninquiry, Preventive Detention, and Comparative Legal Analysis’ (1999)13 (1) US. Federal Courts in Extradition Matters, p 27. 68 Mandel, M.How America Gets Away With Murder, Pluto Press, London, 2004, p 224.Decision by the Appellate Committee of the House of Lords, 15 January 1999 (Pinochet II).(2000) 1AC 119.

69 Ibid. p 230

70 Article 13(b) of the Rome Statute.

71 Gowlland-Debbas, V. 'The Relationship between the Security Council and the Projected International Criminal Court' (1998) Conflict and Security Law, p 99.

72 Ibid. 
- $\quad$ The Security Council has the right to trigger the jurisdiction of the ICC by referral to it of particular matters when it is acting under Chapter VII of UN Charter, thus providing a legal basis for the exercise of its competence. Therefore, the Security Council has the right to refer the crimes in Fallujah Battles, which were committed by CF to ICC.

- $\quad$ The Security Council must define the term 'act of aggression', as the term has not been defined in the Rome Statute. According to Article 39 of the UN Charter, the UN Security Council is charged with determining whether or not an act of aggression has taken place. Such a determination must be made prior to such a matter being referred to the Prosecutor of the ICC.

- The UN Security Council is empowered to prevent the investigation or prosecution of persons by the Prosecutor of the ICC pursuant to a resolution issued by the UN Security Council under Chapter VII of the UN Charter.

\section{Conclusion}

This article provides an IHL analysis of acts committed by the CF during the Fallujah Battles between April and November 2004. The analysis was premised upon IHL instruments, such as the Geneva Conventions, the Additional Protocols and other relevant conventions, and explored grave breaches of IHL that occurred during the hostilities.

This article demonstrates that the CF has violated Common Article 1 of the Geneva Conventions, which requires that parties to the Geneva Conventions respect the Conventions in all circumstances. ${ }^{73}$ The analysis has confirmed that actions of the CF in Fallujah violated Common Article 3 of Geneva Conventions and Article 33 of the Fourth Geneva Convention on the basis that the CF did not adequately protect civilians from military attacks. The military acts of the CF during the Fallujah Battles amounted to collective punishment and aggression against the civilians and their property. Such crimes are considered grave breaches of IHL, specifically under Article 147 of the Fourth Geneva Convention. The civilians

73 Article 1 of Additional Protocol I to the Geneva Conventions. 
and their property were subjected to repeated attacks, rather than enjoying protected status from the occupying power as mandated by the Geneva Conventions.

The CF was responsible to ensure the protection of civilians in Fallujah during wartime because of the CF's status as the occupying power in Iraq. However, the CF not only violated IHL by attacking civilians, but also through the use of white phosphorus in close proximity to civilians in Fallujah. Although the CF was authorized to restore public order and safety in Iraq, its actions in Fallujah amount to international crimes and the individuals responsible should be held accountable. The legal mechanisms that may be used for the prosecution of members of the CF who committed international criminal consist of special tribunals established by the UN Security Council, national courts and the ICC.

\section{Acknowledgement}

The authors would like to express their gratitude to Universiti Kebangsaan Malaysia for sponsoring this study under the Project Code: UKM-UU-05-FRGS0082-2009.

\section{References}

Aksar, Y. 2004. Implementing International Humanitarian Law: From the Ad hoc Tribunals to a Permanent International Criminal Court, Psychology Press.

Aksar, Y.2004. Implementing International Humanitarian Law from the Ad Hoc Tribunals to a Permanent ICC,Routledge, USA and Canada.

Amnesty International, MDE 14/056/2004, News Service No: 287, 14 Nov 2004.

Bantekas, I and Nash, S.2007.International Criminal Law, Routledge Cavendish, USA.

Busby, C., Hamdan, M. \&Ariabi, E. 2010.Cancer, Infant Mortality and Birth Sex-Ratio in Fallujah, Iraq 2005-2009.International Journal of Environmental Research and Public Health, 7, 2828-2837. 
Byers, M. 2007.War Law: Understanding International Law and Armed Conflict, Grove Pr.

Convention (IV) respecting the Laws and Customs of War on Land and its annex: Regulations. Concerning the Laws and Customs of War on Land. The Hague, 18 October 1907.

Floyd. C. 2010. Devastating Aftermath of Fallujah Battle (Online) http://www.darkgovernment.com/news/devastatingaftermath-of-fallujah-battle/ (08April 2011).

Gowlland-Debbas, V. 1998.The Relationship between the Security Council and the Projected International Criminal Court. Journal of Conflict and Security Law, 3, 97.

Interview with Gen. Rich Natonski. The commander of the Marine division during the Fallujah Battles (Online) http://www. youtube.com/watch?v=0vGmScPNB5U (27March2011).

Jeff Englehart and his testimony in the Fallujah, the hidden massacre film, which were presented in Italian channel documentaries.(Online) http://video.google.com/videoplay?d ocid $=8905191678365185391 \#$ (25March 2011).

La Haye, E. 2008. War Crimes in Internal Armed Conflicts, Cambridge Univ Pr.

Letter from Fallujah to Kofi Annan. 2004. (Online)http://www. uruknet.info/?p=9922 (28October2010).

MacLeod. I.J and Rogers A.P.V. 2009.The Use of White Phosphorus and the Law of War.Yearbook of International Humanitarian Law. Volume10. pp. 75-97. No publisher.

Mandel, M. 2004. How America Gets Away With Murder: Illegal Wars, Collateral Damage and Crimes against Humanity, Pluto Press.

McDonald, Gabrielle Kirk and Olivia Swaak-Goldman.2000. Substantive and Procedural Aspects of International Criminal Law: The Experience of National and International Courts. Vol. 1. Dordrecht: Kluwer Law International. 
Meron, Theodor. 1989. Human Rights and Humanitarian Norms as Customary Law. Oxford: Clarendon Press.

Meštrovi , S. G. 2008. Rules of Engagement?: a Social Anatomy of an American War Crime--Operation Iron Triangle, Iraq, Algora Publishing.

Monitoring Net of Human Rights in Iraq Environmental. 2008. Prohibited Weapons Crisis, The effects of Pollution on the Public Health in Fallujah. Presented to 7th Session of the Human Rights Council. Geneva, 3 - 28 March .

Popham, P, the Independent Newspaper, 08 November 2005 http:// www.thewe.cc/weplanet/news/americas/us/war crimes fallujah.html (19 October 2010).

Roberts, Adam and Richard Guelff.2000. Documents on the Law of War. $3^{\text {rd }}$ Ed. Oxford: OUP.

Shimko, K. L. 2010. The Iraq Wars and America's Military Revolution, Cambridge Univ Pr.

Solis, G. D. 2010. The Law of Armed Conflict: International Humanitarian Law in War, Cambridge Univ Pr.

State Parties of Geneva Conventions of 12August 1949.(Online) $\underline{\text { http:// }}$ www.icrc.org/ihl.nsf/WebSign?ReadForm\&id=375\&ps=P (22March2011).

Testimonies of Crimes against Humanity in Fallujah, Report of Conservation Centre of Environmental \& Reserves in Fallujah (CCERF) is recorded in Iraqi Ministry of Planning \& International Cooperative under No. 1Z2129.

Testimony in the Fallujah, the hidden massacre film, which were presented in Italian channel documentaries.(Online) http:// video.google.com/videoplay?docid $=8905191678365185391$ \# (25March2011). 
Van Cleave. R. A, 'The Role of United States Federal Courts in Extradition Matters: The Rule of Non-inquiry, Preventive Detention, and Comparative Legal Analysis' (1999)13 (1) US. Federal Courts in Extradition Matter. 